\title{
Advocacy for Participatory Rural Development. A Comparison of Two Case Studies from Romania AND AUSTRIA ${ }^{1}$
}

\author{
Kinga Xénia HaVADI-Nagy, Oana-Ramona Ilovan, both Cluj-Napoca, \\ Doris Damyanovic, Florian REINWALD, and Mandy MăRGINEAN, all Vienna \\ [Wien]*
}

with 4 figures in the text

\section{Content}

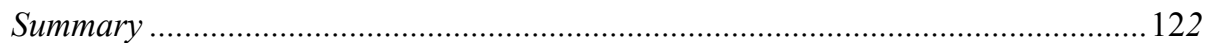

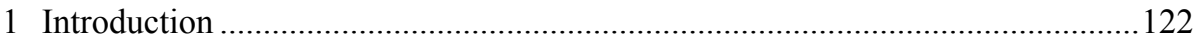

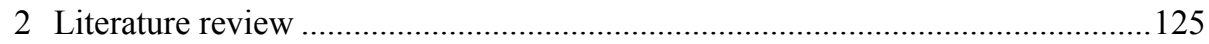

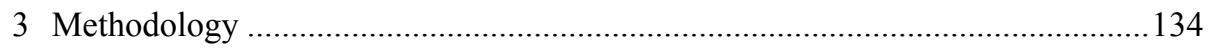

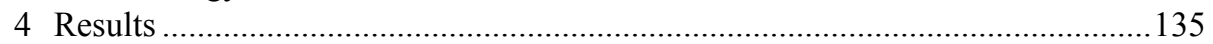

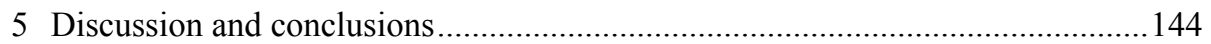

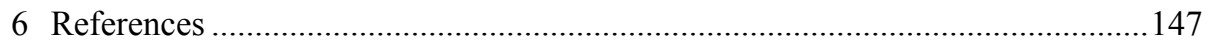

$1 \quad$ Acknowledgements: The village-renewal process in Parndorf/Pandrof was financed by the European Agricultural Fund for Rural Development and the Office of Burgenland State Government Directorate of the State Office - Office of Planning and Housing Subsidies, Unit Village Renewal [Amt der Burgenländischen Landesregierung Landesamtsdirektion Stabsstelle Raumordnung und Wohnbauförderung, Referat Dorferneuerung] and the evaluation study by the Association "Our Village" [Verein unser Dorf]. The research reported in this paper for the Romanian case study is partly funded by the Romanian National Council of Scientific Research in Higher Education (CNCS - UEFISCDI) and the Austrian Agency for International Cooperation in Education and Research (OeAD), as part of the bilateral research programme PN-II-CT-RO-AT-2013 - 1. We are grateful to all our respondents from the individual research projects and from the bi-lateral research project.

* Kinga Xénia Havadi-Nagy, Lecturer, PhD., Oana-Ramona ILovan (corresponding author), Lecturer, PhD., both Department of Regional Geography and Territorial Planning, Faculty of Geography, Babeş-Bolyai University, Strada Clinicilor 5-7, RO-400006 Cluj-Napoca, Romania; email: xenia.havadi@ubbcluj.ro; oana.ilovan@ubbcluj.ro; Doris Damyanovic, Assistant Professor, PhD., Florian Reinwald, Senior Scientist, Mandy Mărginean, University assistant, $\mathrm{PhD}$. Candidate, all Department of Landscape, Spatial and Infrastructure Sciences, Institute for Landscape Planning, University of Natural Resources and Life Sciences Vienna, Peter-JordanStraße 82, A-1190 Wien, Austria; email: doris.damyanovic@boku.ac.at; florian.reinwald@boku. ac.at; mandy.marginean@boku.ac.at 


\section{Summary}

In this paper, we introduce and discuss rural regeneration, starting from the existent theory and from two case studies: Viscri/Deutsch-Weißkirch (Romania) and Parndorf/Pandrof (Austria), with empirical research background. These case studies are good practice examples for the economic and social recovery of rural communities. With all the economic and social challenges faced by rural areas in general, the important research question of the paper refers to the chances of comprehensive rural renewal strategies based on social capital and participation. The objectives of this paper are: (1) to give an overview of the discussions on social capital at the international level, both from the academia and from the significant international organisations, completed by discussions in Romania and Austria; (2) to present different endeavours of participative development strategies in rural areas based on social capital; (3) to identify the level of transferability of these procedures in both countries. The aim of the comparison of the two case studies is to identify and point out the similarities and differences between the two different approaches of participative rural development and the role of social capital for the success of this kind of bottom-up initiatives. We concluded that for the experiences gained in Viscri/Deutsch-Weißkirch and Parndorf/ Pandrof, the central challenges were - despite rather different circumstances and framework conditions - quite similar and were mostly depending on social capital.

\section{Introduction}

In this paper, we introduce and discuss rural regeneration, starting from the existent theory and from two case studies: Viscri/Deutsch-Weißkirch (Hungarian Szászfehéregyház), Brașov County, Transylvania [Transilvania] region, Romania, and Parndorf/Pandrof, Political District Neusiedl am See, Federal State of Burgenland, Austria, with empirical research background. These case studies are good practice examples for the economic and social recovery of rural communities, based on principles of participatory development, with decisive contribution of social capital. As the Romanian example is a bottom-up initiative and the Austrian example a bottomup initiative within a top-down strategy to recovery, the case studies highlight potential and challenges of the different procedures.

The two contrasting case studies from the point of view of the development approach are both good practice examples of operationalising a capacity-building agenda of the respective communities, so that they are able to identify priorities and opportunities in their development and in promoting a necessary social change. Still, we cannot speak of a well-specified intervention model, but only of a set of broad principles in this respect. (As it was concluded also in a study of capacity building 
at the neighbourhood level by CHASKIN et al. 2001.) In this research, we took into account the four major strategies generally used during community-building efforts that we could identify completely or partly in our two research areas: "leadership development, organizational development, community organizing, and fostering collaborative relations among organizations" (CHASKIN et al. 2001, p. 299).

With all the economic and social challenges faced by rural areas in general, the important research question of the paper refers to the chances of comprehensive rural renewal strategies based on social capital and participation.

The objectives of this paper are: (1) to give an overview of the discussions on social capital at the international level, both from the academia and from the significant international organisations, completed by discussions in Romania and Austria; (2) to present different endeavours of participative development strategies in rural areas based on social capital; (3) to identify the level of transferability of these procedures in both countries.

The aim of the comparison of the two case studies is to identify and point out the similarities and differences between the two different approaches of participative rural development and the role of social capital for the success of this kind of bottom-up initiatives.

Considering national and European definitions, both surveyed countries are predominantly rural. Around $87.1 \%$ of Romania is considered of rural character and, as stated by the last census from 2011 , about $45 \%$ of the total population lived in this area (PNDR 2014, p. 57). According to DINCĂ (2012, p. 78), the rural population is dominant in Romania because some villages are part (from an administrative perspective) of many towns and municipalities, while plenty of these hardly could be considered as part of the urban area of Romania, as many do not comply with the conditions imposed by legislation for the status of town.

Similarly, the Eurostat defines $79.2 \%$ of the Austrian territory predominantly rural and $11.9 \%$ of intermediate character. In this territory, there lived $66 \%$ of the population in 2012 (Federal Ministry of Agriculture, Forestry, EnVironment AND Water Management 2016, p. 156). Within the Study Programme on European Spatial Planning, the Federal State of Burgenland was rated in the category "rural area under metropolitan influence" and "region without city > 50,000 inhabitants" (SPESP 2000). During the European funding periods 1995-1999 and 2000-2006, the NUTS II region Burgenland was "objective one area" (with GDP below 75\% of the European average). During the 2007-2013 period, it had the "Phasing-out-Status" and, in the present funding period, it is still a "transition region" (ERDF).

In this context, when talking about social capital and of participative strategies of development in countries with considerable different histories, it is important to point out the background and the major defining elements of the surveyed territory, namely the rural areas of Romania and Austria. 
It is acknowledged at the European level that the rural areas face, almost in the whole European Union (EU), general challenges like: (1) structural changes in agriculture, which induce loss of jobs, (2) lower average income than in towns and cities, (3) narrower skills base, (4) less-developed service sector, (5) thinning of education, health care supply services, (6) selective emigration of young, better educated people with initiatives causing an unfavourable demographical structure with little potential for innovation (EU, Directorate-General for Agriculture and Rural Development 2010, pp. 12-28). This applies to large parts of Austria and of Western Europe, but a lot stronger to the transition countries of Eastern Europe and as well to Romania. Whereat in Romania, we can add the still ongoing implementation and upgrading of basic utilities and facilities (such as public water supply, sewage management, heat distribution system), and the lack of amenities in everyday life comparing to the urban areas.

Many disadvantages and challenges faced by the rural space in transformation countries are not recent, as already in the Communist era, the area faced various socioeconomic problems, low quality of life and unfavourable economic and demographical phenomena. The political turn in 1989/90, in Romania, and the diverse structural changes aggravated the situation almost everywhere (ILOVAN 2006; ILOVAN \& SOCHIRCÃ 2011), except for the rural areas with favourable tourism activities (ILOvan \& MARoşı 2015), for those areas located along development axes between larger urban centres and along borders towards countries with more successful economies. As identified by JORDAN et al. (2016) in their research project about innovative initiatives of development in the Romanian and Austrian rural space (conducted in 2014-2015), the general reasons for the socio-economic decline of the rural areas are (JoRDAN et al. 2016, pp. 203-218):

- the rural area receives less investment than the urban regions;

- the rural area in transformation countries receives much less subsidies from European or national sources compared to the Western European one. Therefore, the rural economy is much more dependent on market prices and income in agriculture, which is usually low compared to income in other branches of the economy;

- the forced opening of the agricultural markets of transformation countries towards the world market resulted in the intrusion of powerful competitors from the EU and from overseas, not only with agricultural production in the narrower sense, but also with foodstuff based on agricultural products. This led to an unfair competition with the local producers and products;

- the improper land restitution system of the post-Communist land reform resulted in economically weak small and medium-sized agricultural enterprises, mostly with subsistence or half-subsistence use;

- much in contrast to the old EU members, also administrative, social, economic, and advisory supportive structures are in an incipient stage. The local administrations have limited planning and financial capacity, in order to absorb 
EU funding. Moreover, they are facing high levels of bureaucracy in the relationship with the management authorities from the regional and national levels;

- migration flows are directed towards better economic prospects, urban areas or abroad. This selective migration leaves older, less qualified and less active, also politically structure-conservative people behind, with lower level of entrepreneurship;

- in Romania, an insufficiently defined rural development concept hinders significant progress. Improper and uncoordinated applications of EU policies counteract each other to the disadvantage of environment, economy, and society.

We can conclude that in rural Romania agriculture is still the economic driving force, the diversification of the economy to other sectors is in progress, but limited, and there is a partly dependence on the financial input from the active labour force working abroad. Further on, the Western European older EU members have a head start on the one hand in adjusting to the EU regulations and, on the other hand, benefitting from the advantages of certain implemented policies.

\section{Literature review}

In this paper, we document two different approaches in building community capacity and in participatory rural development. For understanding those approaches and researching them, the main term we focused on was social capital.

Scientific literature on social capital is very rich. The term is defined and analysed either per se or in relation to a series of terms such as: governance, power and empowering people methods, economic capital, participatory rural appraisal (PRA), community development, public participation, decentralisation, 'town-gown' relations (i.e. universities and their role in community development), NGOs, public policies, community-building agendas and community capacity, liberal democracy, traditional and modern societies, etc.

First, we make a short presentation of the discussions on social capital at the international level: both academia's endeavours and those of the significant international organisations. Secondly, we present the way social capital was documented and discussed in Romania (theory and practice) and thirdly, we introduce similar discussions in Austria.

The aim of this literature review is to underline the diverse opinions we took into account when doing research on the two case studies and when interpreting research 
results, because both theory and practice guided us to consider the available social capital as one of the crucial success factors of village renewal and development in general.

\subsection{Academic approaches to social capital}

At the international level, there are several well-known studies. For instance, Bowles \& GiNTIS (2002) defined and discussed social capital and community governance from an economic point of view. They also defined social capital as referring to "trust, concern for one's associates, a willingness to live by the norms of one's community and to punish those who do not. These behaviours were recognised as essential ingredients of good governance among classical thinkers from Aristotle to Thomas Aquinas and Edmund Burke" (p. F419). In addition, communities are seen as part of the good governance, due to their specific problems that cannot be solved at the individual level or by factors outside the community (Bowles \& Gintis 2002, p. F421).

CASTLE argued for an interdisciplinary interpretation of social capital applied to rural studies. The 1980s and the 1990s registered a wide use of this term in social sciences (economics, sociology, and anthropology) in general and in rural studies as well. He mentioned that no single discipline can obtain the insights and knowledge that this interdisciplinary concept needs in order to assess its usefulness for development and for society (p. 331). Political science is another field researching this type of capital, and also geographers study rural communities and that is why this term was useful in our paper and during field research.

CASTLE also underlined that there are also those (economists and sociologists) who considered this concept as a threat (p. 347). In this contesting view, also DeFILIPPIS (2001) gave proof that PuTNAM's vision on social capital is not useful as social capital "is a fundamentally flawed concept because it fails to understand issues of power in the production of communities and because it is divorced from economic capital" (p. 781). He considers that this "term has lost its potential utility for the community development movement" and that it is "imbued with the assumption that social networks are win-win relationships and that individual gains, interests, and profits are synonymous with group gains, interests, and profits" (DeFiLIPPIs 2001, p. 781). He also was very specific about the fact that there are people excluded from those networks of social capital who realise economic capital (p. 801). Referring to innercity neighbourhoods, he underlined that those communities "have social networks and trust between members of those networks, and they possess many nongovernment, community-based organisations. What they lack is power and the capital that partially constitutes that power. They are not likely to realise either without confrontation or within a Putnam-inspired framework of community development" (p. 801). He argues that social capital needs money to function and money empowers people, making them 
able to create or develop their trust-based networks and that the solution of truly winwin relationships for people in poor areas is to build social networks that function because they use as a basis the existing social networks and relationships (DEFILIPPIS 2001, p. 801). Nevertheless, beside the financial capital, also other elements are important, such as access to land, infrastructure, power, and the social capital available (Damyanovic \& Reinwald 2014).

CHAmbers in two of his best known and influent studies (1994a, 1994b) advocated for the use of PRA, which he defined as "a growing family of approaches and methods to enable local people to share, enhance and analyse their knowledge of life and conditions, to plan and to act" (1994a, p. 953). He differentiated between rapid rural appraisal (RRA) and PRA focusing on the way information is collected and used: "In RRA information is more elicited and extracted by outsiders; in PRA it is more shared and owned by local people" (ChAmBers 1994a, p. 953). ChAmbers (1994b) underlined the role of outsider facilitators and of PRA as a complex of methods for collecting data and empowering local people in the process of making demands (p. 1253, p. 1266): "Evidence to date shows high validity and reliability of information shared by local people through PRA compared with data from more traditional methods" (p. 1253).

On this issue of empowering the weak and the poor in general, Arnstein (1969) discussed citizen participation in an attempt to clarify diverse degrees of manipulation and empowerment. She defined citizen participation as "the redistribution of power that enables the have-not citizens, presently excluded from the political and economic processes, to be deliberately included in the future. It is the strategy by which the have-nots join in determining how information is shared, goals and policies are set, tax resources are allocated, programmes are operated, and benefits like contracts and patronage are parcelled out" (ARNSTEIN 1969, p. 216), and for a specific description of each type of participation she devised a ladder in which each rung corresponded to the citizens' power in influencing the result of their co-operation with public administration in taking charge of their lives and of their community development (ARNSTEIN 1969, p. 217).

Participatory rural development comes along with a series of other closely connected terms such as decentralisation, sustainable development, and rural development policy, as AHMAD \& TALiB (2011) pointed out in their literature review. Therefore, they considered the role of decentralisation as a policy of rural development and underlined that it had been largely used in many developing countries since the 1970s (AhMAD \& TALIB 2011, p. 65) in "achieving important goals and objectives of concern programmes such as people participation, local democracy, transfer of decision power to people, need based relevant development, co-ordination, integration and debureaucratic setup" (AHMAD \& TALiB 2011, p. 59, apud CONYERs 1986).

BINNS et al. (1997) argue that PRA is a step forward in what local people's perceptions, needs and understanding are concerned and support geographers' experience in field research and in interpreting people-environment relationships that 
are so useful, in comparison to rather failing centrally driven approaches, for identifying suitable development strategies where communities, which a series of programmes assist, are true partners.

CHAskin et al. (2001) considered that social capital was useful for building community capacity, which they defined as "the interaction of human capital, organizational resources, and social capital existing within a given community that can be leveraged to solve collective problems and improve or maintain the well-being of a given community. It may operate through informal social processes and/or organized effort" (p. 295).

PeArce (1993) realised an analysis of NGOs' activities and concluded that their influence is strong due to "networking, coordinating, advocacy, and developing a strategic way of thinking" (p. 222). Similarly, FukUYAMA (2001) considers that NGOs are a form of trust like groups of friends, cliques, and religious groups (p. 8).

Fukuyama (2001) defines social capital as "an instantiated informal norm that promotes co-operation between individuals. In the economic sphere it reduces transaction costs and in the political sphere it promotes the kind of associational life which is necessary for the success of limited government and modern democracy" (p. 7). He argues that it originates in habitual and practiced co-operation, in religion, tradition, shared historical experience and other types of diverse cultural norms (FukUYAma 2001, p. 7) and he underlines the particular situation of post-Socialist societies, which have no trust or sustainable and functional civil society: "If the state gets into the business of organising everything, people will become dependent on it and lose their spontaneous ability to work with one another" and "the Communist Party consciously sought to undermine all forms of horizontal association in favour of vertical ties between Party - State and individual" (Funuyama 2001, p. 18). Moreover, property rights and safety are important for breeding social capital (FuKUYAMA 2001, p. 18). In Romania, the burden of the Communist Party actions may explain the lack of trust.

\subsection{International organisations' approaches to social capital}

During the last decades, a series of international organisations got involved into rural sustainable development approached through bottom-up activities. As a result of this participation, these organisations published literature documenting both theory and practice.

For instance, OAKLEY et al. (1991) discussed popular participation, rural community, rural development, and development project/s in relation to developing countries in a publication prepared with the financial support of the United Nations Food and Agricultural Organisation (FAO), the United Nations Development Fund for Women (UNIFEM), and the United Nations World Health Organisation (WHO). 
Similarly, the Rural Institutions and Participation Service, Rural Development Division of the Food and Agriculture Organisation of the United Nations published "Participatory Development: Guidelines on Beneficiary Participation in Agricultural and Rural Development" (van Heck 2003). They mentioned that "these guidelines provide guidance for policy makers and practitioners how to incorporate group-based, participatory based approaches into large-scale investment projects. They included advice on a range of topics: strategies to promote participation, project formulation, group formation, financial arrangements, training, monitoring and evaluation, etc. They were based on experience gained in the design and implementation of FAO People's Participation Programme projects during the 1980s" (VAN HECK 2003, p. ii). Moreover, the Rural Development Division of the Food and Agriculture Organisation of the United Nations also published a methodological approach to participatory and negotiated rural territorial development (FAO-RDD 2005).

In addition, the United Nations Economic and Social Commission for Asia and the Pacific (ESCAP) published "Participatory Approaches to Rural Development and Rural Poverty Alleviation" (DE CAMpos GuimarÃes 2009). This document is useful for our present research as it focused on the historical background in rural development, on definitions and typologies of participation, on PRA, and on the ideologies, current debates and challenges of participation.

The same year as above, the International Bank for Reconstruction and Development and the World Bank published "Participatory Communication. A Practical Guide" (Tufte \& Mefalopulos 2009), discussing the conceptual challenges in a participatory communication model, the usefulness of applying participatory communication in development projects, and participatory communication in civil society (with special focus on community empowerment, participatory governance, social mobilisation and bottom-up advocacy, and the lessons learned).

\subsection{Romanian approaches to social capital}

The case of social capital and capacity building of communities was documented in Romania. For instance, HARUȚA \& RADU (2010) took into account ARnSTeIn's ladder of participation (1969, p. 217) and concluded that in Romania, at local and county level, public participation was only in the form of consultation, as political and administrative officials had all control over the decision-making process (p. 76).

Alexiu et al. (2011), in a study exploring community participation for efficiently using resources and for increasing social solidarity in the rural area, also concluded that community participation reached only the first level, that was information sharing (p. 21). They underlined the local public authorities' lack of initiative in involving local people into solving problems of their community (ALEXIU et al. 2011, p. 21). They also pointed out a useful discovery for our case study on Viscri/Deutsch-Weißkirch: 
"a longer distance [from the centre] involves an increased availability in citizens' involvement in social actions" (Alexiu et al. 2011, p. 21).

There are two possible explanations that research on Romania and its rural space situation, from an administrative perspective, give to the lack of or the low community participation. On the one hand, researchers consider that people may perceive participation as a means to achieving their individual goals and welfare: " $\mathrm{A}$ possible explanation for this situation could be the attitude of the community members towards the community participation: maybe they perceived it not as means for social cohesion, as we thought, but as an instrument for achieving their individual welfare, not having any connection with the group interest, but serving solely to the one using it" (AleXIu et al. 2011, p. 21). This is supported also by another study that documented the common lack of trust in post-Socialist Romania: "In Romania, as well as in other post-communist countries, survey data show the diminishing social trust, both under its general and institutional form. For the first case the reason lies in corruption, in institutional un-accountability, etc. At the same time, people develop trust in informal support networks" (NISTOR et al. 2011, p. 172).

On the other hand, other researchers consider that the lack of initiative for cooperation with the citizens is starting at the administrative local level and the reasons are diverse, but all having the same cause, which is resistance against decentralisation: "It is necessary to unleash the local initiative and responsibility from the vicious circle maintained by: the resistance against the decentralization of those who, both in politics and in the administrative area, see their powers amputated due to decentralization; disclaimer of the initiative by local leaders, favoured by the low participation of other local actors; insufficient administrative capacity at the local level; lack, at a central level, of skills and mechanisms to ensure implementation of policies in decentralized system; lack of necessary intersectoral coordination capacity to satisfy an integrated mood to the needs and local programmes development; inadequate monitoring of transfer of power to the local level, resulting in the absence of accompanying support mechanisms and failure of necessary corrections." (DINCÁ 2012, p. 90)

NisTOR et al. (2011) analysed formal, informal and community level volunteering and their roles (as types of social capital) in producing trust, starting from the assumption that social capital described "social interaction and involvement, social trust and civil norms, etc." (p. 156). They discovered that, in Romania, informal networks compensated for weak formal ones or led to accessing them (NISTOR et al. 2011, 172).

BALOGH (2012) argued for the appearance of a paradigm shift in the present implementation of local development policies that involved the increasing role "of NGOs in meeting the needs and interests of the community", in influencing public policy, in providing services, in promoting change, and in stimulating community selfhelp networks and groups (p. 29). 


\subsection{Austrian approaches - village renewal as a means to develop social capital}

In a wider perspective, the citizens' relation with a pro-active public administration has a long tradition in Austria. At the state level, the strong cooperation between interest groups and associations is known under the term of "Social Partnership" [Sozialpartnerschaft] since World War II and it is based on no laws, but on the stakeholders' voluntary will. Although informal to a considerable extent, this cooperation has a significant influence on political decision-making concerning certain policies: income policy, parts of the economic and social policies, the agricultural markets, labour market, and equal treatment policy. The recent decades of economic, social and political stability in Austria are indebted to this form of social partnership (BundeSPRESSEDIENST 2000, pp. 26-28).

Public participation is a broadly accepted approach in Austria regarding decisions in the planning and development context. Starting in the 1970s, the traditional topdown decision making in planning processes came under pressure. Starting with participation processes on project level, participation became an integral part of many planning instruments and processes. Especially since the mid-1990s, the discussions at the European level regarding the implementation of sustainable development and the Charta of Ålborg also influenced the Austrian strategies on rural development and participation. The National Environmental Plan published in 1994 was the second strategy for sustainable development at the national level in Europe. Public participation and the involvement of NGOs were two of the guiding principles for sustainable (rural) development (ÖSTERREICHISCHE BUNDESREGIERUNG 1996). Also within the current Austrian Strategy for Sustainable Development, public participation is a central approach. Participation supports the acceptance of measures regarding (spatial) development (BMLFUW 2002, p. 63).

Quality assurance and democracy are central elements for successful participation processes. Therefore, in 2002, at the initiative of the Ministry of the Environment, a 'Strategic Group on Participation' was installed to promote participation in Austria. They focused on contexts and quality criteria for participation processes and the limits and obstacles to participation. The Public Participation Manual, including definitions, standards, success factors and case studies, was an important strategic publication of this group (BMLFUW \& ÖGUT 2007). In 2008, the Austrian Federal Chancellery and the Austrian Federal Ministry of Agriculture, Forestry, Environment and Water Management published the Standards of Public Participation. Recommendations for Good Practice as a guiding manual for participation procedures including minimal standards (Austrian Federal Chancellery \& BMLFUW 2008/2011). They defined principles for the implementation in Austria, like transparency, respect, fairness and also differentiated among different forms of participation like information, consultation, and co-decision. 
Another strong influence on the participation processes, especially for the Federal State of Burgenland and its village-renewal programme, was the European Agricultural Fund for Rural Development (EAFRD). In 1995, Austria became a member of the European Union and since then the rural areas - especially Burgenland as a so called "objective 1 area" - benefited from programmes for rural development. The LEADER programme financed by EAFRD supported rural development and the village-renewal programme of Burgenland - in combination with federal state money. Within the last LEADER funding period, from 2007 to 2013, more than 140 of the 171 municipalities of the Federal State of Burgenland were engaged in village-renewal processes.

\subsubsection{Spatial planning and development instruments in Burgenland at the local level}

Two main approaches in village development, which include aspects of participation, are common in Austria and Burgenland: the traditional spatial and landuse planning instruments and the above-mentioned village-renewal approach.

In contrast to Romania, the (spatial) development competences in Austria are much decentralised. Austria has neither national planning legislation, nor planning competences beside the superordinate street system, aviation, railways, navigation and telecommunication, as well as forestry, risk management and energy infrastructure (Art. $15 \mathrm{~B}-\mathrm{VG}$ ). The nine federal states of Austria are responsible for the regulations regarding village development. So, there are nine different spatial planning laws and nine different regulations for village renewal, which are the main planning and development instruments at the local level in Austria, for municipalities. Additionally, the mayor of a municipality and the local municipal council are the building authority in the first and second instance (2,100 municipalities in Austria, as of 2015) and therefore the municipality decides on spatial development at the local level. The federal state is the responsible supervising authority (Art. $118 \mathrm{~B}-\mathrm{VG}$ ).

Within spatial planning, there are three main planning instruments at the local level: (1) the local development concept, which outlines the future spatial development of municipalities for the next 10 to 20 years, (2) the legally binding land-use plan, which assigns the different possibilities of use (e.g. building land, open spaces, traffic) for the next five to ten years, and (3) the zoning plan, which regulates, for example, the building heights or mandatory building lines. The possibilities for participation are limited. For the local development concepts, regularly information events take place to mediate the different interest and development perspectives or (in most cases) just present the development concept. During the growth of the development concept and the land-use plan, it is possible for everyone, during a period of some weeks (depending on the federal state), to hand in comments to the concepts. 


\subsubsection{Comprehensive village-renewal programme in Burgenland to implement LA 21 processes}

The other approach in municipal development is represented by the villagerenewal programmes at the federal state level - also nine different ones. The roots of these village-renewal approaches in Austria are - like in Viscri/Deutsch-Weißkirch - in the protection of historic buildings and the conservation of rural architecture. The revitalisation of old buildings and the renovation of facades were the first task in village renewal back in the 1970s and 1980s. In 1987, the village-renewal programme was first introduced in Burgenland. Since 2007, the village-renewal programme has been combined with the Local Agenda 21 approach, because there are a lot of points of contact and intersections (ARTNER 2004, p. 10). The full name of the programme is therefore "LA21-Village-Renewal Programme of Burgenland". The basis for the "Local Agenda 21" strategy was specified by the European cities and towns at the conference in Ålborg, in 1994 (Charter of European Cities \& Towns towards Sustainability). In 1992, the UN Conference on Environment and Development launched the Agenda 21, a programme, which was signed by 178 states to ensure sustainable development (UNited NATions 1992). One idea was that many of the global problems could be solved on the local level as it was the level of governance closest to the people. "Think global - act local" was the slogan. In Chapter 28 of the Charta, local authorities were asked to start dialogues with citizens and local organisations to develop communal programmes through consultation and consensus-building (United NATions 1992). The aim was to develop sustainable - economic, ecological and social - strategies for the future development of their municipality.

These activities are coordinated at state level by the Sustainability Co-ordinators of the federal states, who meet regularly. The "Joint Declaration on Local Agenda 21 in Austria" is the basis for the implementation of LA 21 processes where they fixed common implementation steps towards LA 21 in Austria (LiAISON OfFICE OF THE Federal Provinces 2003). Central objectives and basic principles, beside sustainable development, are, among others, "help towards self-help", "direct democracy", "social cohesion", and "equal rights between women and men" (LiaIson OfFICE OF THE FEDERAL Provinces 2003). They also stated success factors like external process supervisors or a broad-based participation.

\subsubsection{Social capital in participation processes}

Social capital as a term is not directly mentioned in these documents, but also in Austria a discussion on the importance of social capital and the strengthening of social capital as a key issue in local and regional development are visible (e.g. GeHMACHER 2009; Amt der Vorarlberger Landesregierung, Büro für ZukunftSFragen 2010; BMUKK \& BMLFUW 2010). The social capital concept is also often a basis for 
Local Agenda 21 programmes (Dangschat \& Breitfuss 2002; Hanke 2011; Elbe 2011), and participation and citizen engagement is also seen as an indicator for social capital (Putnam 1993; Falk \& Kilpatrick 2000; Groottaert \& van Bastelaer 2002), and thus as an indicator within village-renewal processes. The enhancement and the mobilisation of social capital is a prerequisite for sustainable village-renewal processes (Damyanovic \& Reinwald 2014).

According to $\operatorname{ELBE}(2011$, p. 79), social capital is characterised by the duality of its characteristics: it is found in various forms and has individual impacts. Subsequently, the range of social capital is subdivided into micro, meso and macro levels (DAMYANOVIC \& ReINWALD 2014).

The micro level refers to the relationship within a family or the inner circle of friends. The meso level or the so-called group level - which is central within participation and village-renewal processes - includes the relationships within a wider group, and, finally, the macro level encompasses the organisational and institutional level of connectivity (Falk \& Kilpatrick 2000; Groottaert \& van Bastelaer 2002; GEHMACHER 2009).

Additionally, regarding the network view, two dimensions of social capital are distinguished: the bonding and the bridging social capital. The bonding social capital refers to the inner connections within a group or community, which holds the group together (Husák 2012, p. 242). The bridging social capital is necessary to connect the group with external contacts (ELBE 2011). Both forms of social capital and the empowerment of these are central for successful village-renewal processes.

\section{Methodology}

For this paper, the collection of data (both theoretical and empirical) had several sources. First, we used data from the literature review of academic and applied research. Secondly, we conducted key-informant focus groups and interviews with people (government officials, foundation representatives, practitioners, entrepreneurs, locals), having diverse roles in community development and in community building especially.

For the case study of Viscri/Deutsch-Weißkirch, informal discussions conducted in the last couple of years, during various occasions, with several villagers and people involved, offered most of the information. Furthermore, the village was also one of the case studies in a joint research project about innovative strategies of rural development, conducted together with Austrian colleagues in 2014-2015. Personal investigations on site and the official web platforms of the village and the involved institutions completed the outlined aspects. 
The empirical data for the description of the case study in Parndorf/Pandrof and the village-renewal programme in the federal state of Burgenland are based on (a) two village-renewal processes where the authors were process facilitators (in the Municipality of Mörbisch - DAMYANOVIC \& REINWALD 2009 - and in the municipality of Parndorf/Pandrof - Damyanovic \& Reinwald 2010), (b) on the results of a 'mid-term' evaluation of the comprehensive village-renewal programme (DAMYANOVIC \& REINWALD 2014), and (c) on considerations regarding the future development of the programme within the new funding period starting in 2014 (REINWALD et al. unpublished).

The village-renewal processes consist of a participation procedure, but also of a comprehensive analysis of the present situation of the municipalities, including an analysis of social and economic data, as well as a collection of spatial information to analyse social and spatial structures in the municipality.

For the mid-term evaluation of the village-renewal programme in Burgenland, statistical data from the federal state office for village renewal regarding the amount, distribution and contents of village-renewal processes and projects where evaluated and 15 one to two hours expert's interviews with mayors and process facilitators of seven different municipalities were conducted. Additionally, the results were discussed with the politically responsible, the village-renewal advisory board and the administration employees in an expert workshop.

\section{Results}

\subsection{Viscri/Deutsch-Weißkirch and the "Whole Village Project" of the Mihai Eminescu Trust (MET) in Romania}

The village of Viscri/Deutsch-Weißkirch, under the leadership of the local councillor Caroline Fernolend, has attracted international attention as an example for historic built cultural heritage preservation, combined with economic regeneration and community building, and as the foundation for the MET "Whole Village Project" rural development strategy.

Viscri/Deutsch-Weißkirch is a small village with about 450 inhabitants, in a remote hilly area in Braşov County, far away from the main roads, which can be reached on a partially paved road. The village, with its fortified church and typical farmyards, is a well-preserved sample of the Saxon rural settlements common in Southern Transylvania, which, during their more or less 800 years of history, constituted substantially the typical cultural landscape prevalent in this area. No more than a few years ago, an insignificant village, at present, Viscri/Deutsch-Weißkirch enjoys great popularity due to its architectural heritage (the Evangelical fortified church - Fig. 1 and Saxon farmyards), which has been listed as UNESCO cultural heritage since 1999 
and, furthermore, thanks to the several successful projects conducted here for and by the community, which turned them into a good practice model of local governance and of participatory rural development.

Although without a theoretical background or an available guide book, the approach initiated by councillor Fernolend applies the principles of empowerment participation, which implies a high share of citizen's involvement in every stage of the development: initiative, decision making, strategy development with specific measures, implementation and, finally, evaluation. Primary stakeholders, outsiders, and experts are equal partners in the development effort, where dialogue and exchange of knowledge and experiences lead to solutions.

Figure 1: The Evangelical fortified church in Viscri/Deutsch-Weißkirch (Photo courtesy of Michael ScHNEEBERGER)

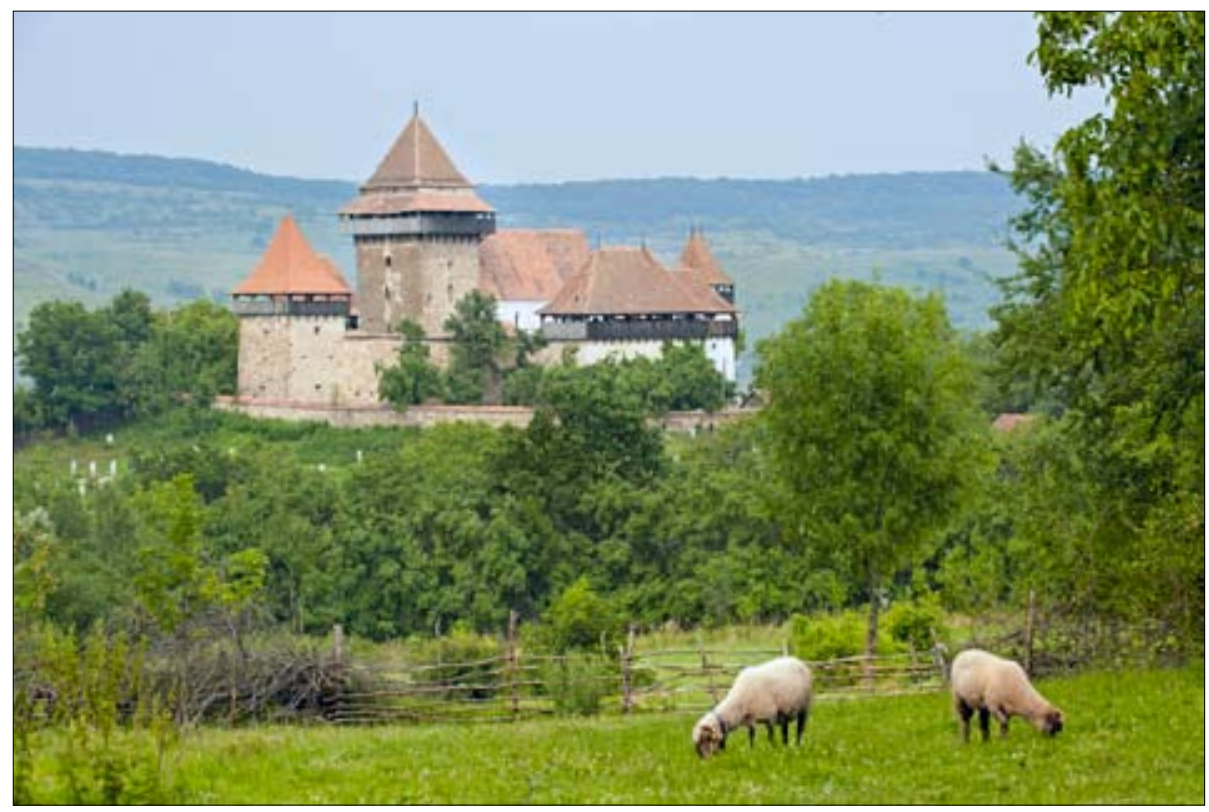

The first common project of the villagers was the renovation of the school. The conservation of the built cultural heritage turned into one of the main pillars of the development and regeneration process. The rehabilitation of the old houses and buildings is not considered a plain ideal mission, as there are actually pragmatic reasons for their reconditioning and revitalisation, as well as the endeavour to establish soft tourism. The incentive for the work of the citizens' initiative was in fact the need. In the early 1990s, in the aftermath of the political changes, there were scarce possibilities for people to earn their living: the closure of the former agriculture collectives and the structural changes in economy left most of the villagers unemployed. Furthermore, a 
large number of the Saxon population emigrated, the exodus causing a caesura and putting the economic and social functioning of the village community in danger. ${ }^{2}$ Together with the Saxons, what also disappeared was the knowledge required for the maintenance of the traditionally built houses, as well as the will and desires to cherish the culture and the material artefacts of their presence in this region, over several centuries. The new inhabitants of the former Saxon courtyards possessed neither the knowledge and skills, nor the resources to preserve the buildings and the adjacent infrastructures.

Inspired by the Saxon community, which in its several centuries of existence in Transylvania had to cope with and overcome various difficulties and challenges, the present leaders of the Viscri/Deutsch-Weißkirch community aim to connect with the former Saxon community's mind-set, focused on common welfare. The prime feature of the Transylvanian Saxons is considered to be their capacity and 'spirit' of self-government. This is why the strategy is to continue with the tradition of local responsibility, to educate the present population in the sense of pre-occupation and involvement in the formation and maintenance of the common good, applying practices in the spirit of the nowadays well-known principle of subsidiarity and, finally, to build a new community and identity beyond ethnicity.

As a result, today, the village is managed according to a well-established integrated procedure: from conceiving new projects in compliance with the needs of the community, to target-oriented fundraising activities and to the execution of the works mainly involving local labour and with inhabitants' participation.

During several years, the Mihai Eminescu Trust (MET), dedicated to the conservation and regeneration of villages and communes in Transylvania, mainly in the area of the Saxon villages, had an important part in the conservation of the building fabric, repairing, painting and restoring houses, courtyards, stables' walls, roofs and fences. Presided by Mrs. Fernolend, the Trust trained inhabitants in various professions required in the process of restoration, also with the purpose of ensuring them a stable income source. This process helped also to esteem the traditions of the village and to be aware of the value of the cultural heritage they benefited from.

Initiators of the village management explain that the aim is not to maintain artificially the "back then", nevertheless many historical aspects - such as the traditional houses inhabited now by Romanians, Roma and a few Saxons, the nearly unchanged village structure, the agricultural occupations - define up to present the everyday life and the identity of the local community.

Viscri/Deutsch-Weißkirch is today a popular destination for tourists, but this was not always like that. In the 1990 s, visitors were sporadic in the remote village. Tourism turned into an important source of income mainly after 2000. According to the statistics kept by councillor Fernolend, the number of persons who visited the fortified church and the village increased from 400 in 2000, to 14,000 in 2012, and 30,000 in 2015.

$2 \mathrm{http} / / /$ www.deutsch-weisskirch.ro/?page_id=7 
The historical structures were identified as a potential to be exploited for the benefit of local and regional development. The protection and the preservation of the authentic appearance of the village and of its natural surroundings enjoy priority, as the authenticity of the village is the main factor of attractiveness, and also confers pride and, on a certain level, self-esteem to its inhabitants. Thus, restoration and tourism go hand in hand: the architectural heritage is the main reason why visitors are coming. The restoration works and accommodating visitors ensure diverse income possibilities. Accommodation in rehabilitated Saxon farmer houses, with a certain comfort level, furnished mostly traditionally with antique pieces und several further details, such as the plain fare (simple homemade food), provides the framework for the visitors to experience the nature-bounded course of everyday life of the village. The brick manufacture managed by a local villager and his family has produced for several years the required material for the restoration of the houses in numerous former Saxon villages. Beside the wool products serving also as original souvenirs, homemade brandy or jam are served at meals and can be also purchased. Villagers carry out subsistence agriculture, producing mainly for their own needs and for those who have a guesthouse. A well-equipped milk collection centre offers the chance to make a small income out of the few cows the inhabitants own. Braided baskets for waste disposal were manufactured by a local family, and the villagers are in charge of the disposal of the trash. Horse carriage owners' offer drives in the surroundings. An innovative, biological sewage treatment plant contributes in a sustainable way to environment protection. The next issue to be solved is a parking lot outside the village, so on the one hand the cars do not disrupt the authentic image of the village, but also do not steer up dust or inconvenience agriculture activities and transport.

The "Viscri socks" self-help project for the women of the village came to life independently from the MET activities and turned into a further income pillar for about 100 women. Initiated in 1999, the project developed into a well-functioning small company. The range of products was diversified with wool gloves and hats or even carpet sleepers. The products can be purchased at various stands in the village (Fig. 2), but they mainly send them to Germany and redistribute them also in Austria or in Switzerland through informal social networks. ${ }^{3}$

Significant components of the cultural landscape of the region are also the high nature value farmed landscapes, which are among the most important in Europe. These high-biodiversity landscapes are the result of farmers' work over hundreds of years, characterised by low-input farming and can be preserved only by continuing traditional management. These landscapes are a refuge for many threatened species and habitats, lost in much of Europe and, furthermore, they provide important ecosystem services.

The ADEPT Foundation is one of the most important actors in protecting Transylvania's remarkable farmed landscapes, their biodiversity, and the farming communities who live there. On a certain level, their goal complements the work of

3 http://viscrisocken.insopro.org/ 
the MET: They aim to preserve the natural side of the cultural landscape, and MET is more into the built cultural heritage, yet both advocate for overall sustainable rural development. The foundation, mainly constituted by local and regional active citizens supported by foreign experts, has been working since 2002 with farmers, local communities, universities, other NGOs, and with government at all levels, in order to solve the range of problems threatening the survival of these outstanding landscapes and of the small-scale farming communities living there. According to collaborators, the ADEPT Foundation conducts an innovative sustainable approach carrying out an integrated programme, linking economic and social benefits to biodiversity conservation, and raising local capacity for good management in the future. ${ }^{4}$

Figure 2: Some impressions from Viscri/Deutsch-Weißkirch (Photos courtesy of Michael SCHNEEBERGER)

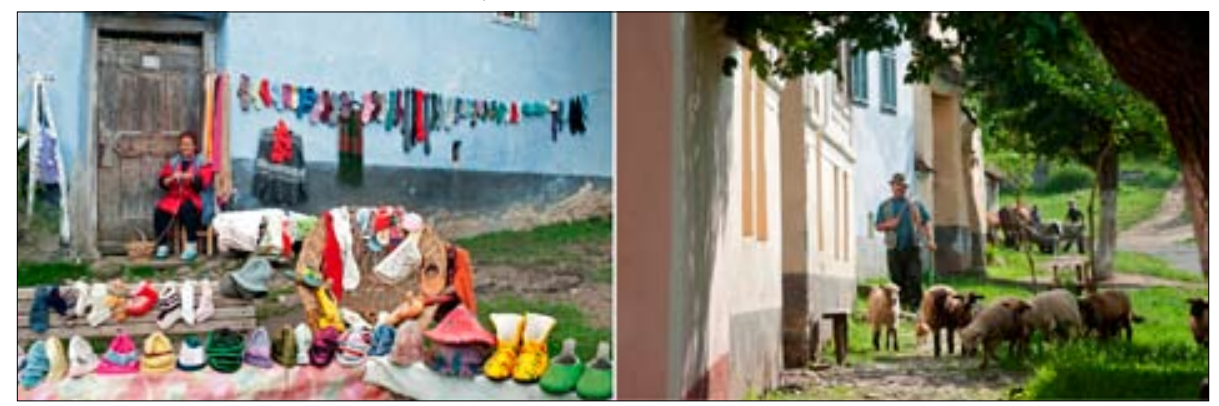

Despite setbacks (difficulties to cope with the sudden massive increase of the popularity of their village and the large number of tourists, partially improper implemented national and European rural development strategies, which endanger the valuable biodiversity and the high nature value farmed landscapes), Viscri/DeutschWeißkirch is a great example for development in accordance with the principle of sustainability, maintaining a balance between the three main pillars: environment, society, and economy.

A positive domino effect is obvious where successful projects serve as a reference in the fundraising action and as support for further programmes. Joint forces, under the guidance of the active and motivated local 'mobilising agent', have resulted in establishing a new community spirit, which aims to preserve the natural and cultural values, employing them in the service for the community.

Mainly in Viscri/Deutsch-Weißkirch, gained experience in economic and social revival, with the participation of the inhabitants, was the foundation for one of the most representative undertakings of the Mihai Eminescu Trust, the "Whole Village Project". The aim is to preserve the villages' fabric, remedy the population's loss of income and revive their sense of community. The work of the Trust not only consists

\footnotetext{
4 http://www.fundatia-adept.org/
} 
of preserving the built cultural heritage, but also of focusing on the village as a whole, with the intention of regenerating the community. Thus, the Trust has developed a working procedure ${ }^{5}$, according to which, in selected villages, it assists the inhabitants to develop new sources of income and to restore their houses with adequate use of traditional materials.

To the present day, the Trust has enabled several hundred houses and several churches in numerous villages to be restored. Confidence is growing that the villages can be brought back to life and that the actual Romanian and Roma population of the former Saxon villages is being integrated into the communities. These successes are influencing regional conservation policy and serving as a model for threatened communities elsewhere.

\subsection{Case study "comprehensive village-renewal process" in the municipality of Parndorf/Pandrof in the Austrian federal state Burgenland}

With the new instrument "comprehensive village-renewal programme" and the integration of LA 21 in the village renewal in 2007, the focal point of village renewal in Burgenland shifted from mainly spatial aspects to a much wider understanding of quality of life in rural areas (DAMYANOvic \& REINWALD 2011a, pp. 18-19). The villagerenewal processes have to take into account ecological, economic, social, and cultural aspects (AMT DER BURGENLÄNDISCHEN LANDESREGIERUNG 2012). The quality of life for everyone is the goal of sustainable development for villages, of small and mediumsized towns in Burgenland.

Burgenland is the easternmost of the nine federal states of Austria, with borders to Hungary, Slovakia, and Slovenia. Approximately 291,023 people live in 171 municipalities (as of 2016 StATISTIK Austria). Until 1989, the so-called 'Iron Curtain' [Eiserner Vorhang] separated Austria from the Eastern countries. This marginality was for many municipalities in Burgenland a challenge especially in the economic sector. As a result, the southernmost and the regions close to the border were economically weaker. But, like in Viscri/Deutsch-Weißkirch, this also leads to the situation that more historical buildings and village structures remained. General trends, similarly to Romania, like the decline of the agricultural sector and migration from rural areas and villages into cities are also noticeable in some parts of Burgenland. Nevertheless, the villages in the northern parts, close to Vienna [Wien], show a strong population growth.

Parndorf/Pandrof is situated in the district Neusiedl am See, $40 \mathrm{~km}$ south-east of Vienna. According to its traffic-convenient location to Vienna, with a freeway and a railway connection to Vienna and Bratislava, the Parndorf/Pandrof community grew 
rapidly in the last 30 years (Fig. 3). The municipality of Parndorf/Pandrof has grown from 2,648 inhabitants in 1991, up to 4,475 inhabitants in 2016 (STATISTIK Austria 2016). Many inhabitants of Parndorf/Pandrof commute for work to Vienna or to other neighbouring cities. In addition, Parndorf/Pandrof provides a high proportion of jobs in the processing industry, which attracts even more people to move here (DAMYANOVIC \& ReInWALd 2010). Nearly $18 \%$ of the population are not born in Austria (as of 2011 Statistik Austria). This strong influx of people and their integration into the social structures of the village are therefore a core topic in municipal development.

Figure 3: Some impressions from Parndorf/Pandrof

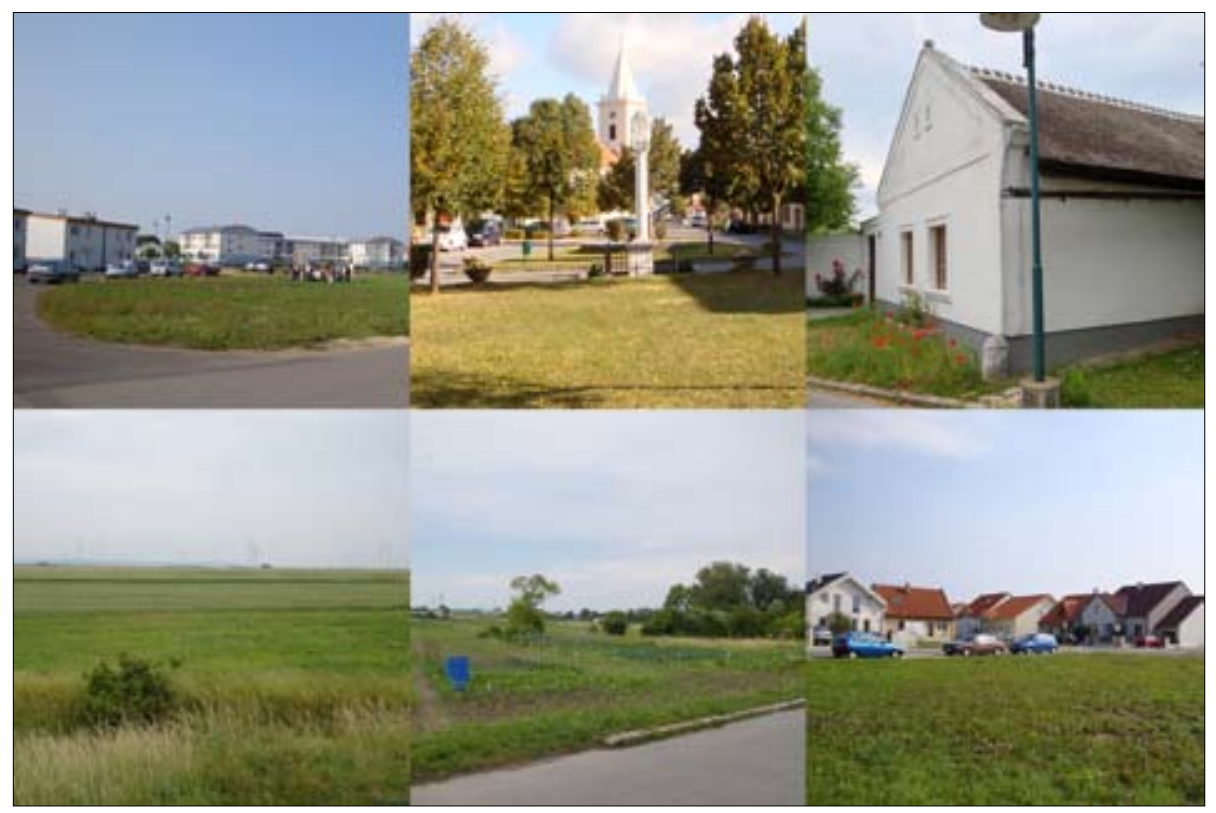

Since 1994, there has been a dedicated group of people from Parndorf/Pandrof active in village renewal. The starting project was the renovation of a chapel. For nearly 15 years, the bottom-up group organised itself and accomplished various village renewal projects, like the design of a barbecue area, the renovation of playgrounds and parks, or Christmas decoration with just a small support from the municipality. They also organised flea and farmer's markets and other social events to support the village community. In 2009, they decided to professionalise their work and entered the "comprehensive village-renewal programme".

The aim of the village-renewal process is to create an overall concept as a vision for village development. According to this vision, measures are getting developed and implemented to achieve the desired development objectives. In compliance with 
the regulation of the federal state, the process is divided into three phases: first, the 'information and preparation phase', where residents get informed about the process and about the goal of village renewal, plus a core team gettig established as a carrier of village renewal. In Parndorf/Pandrof, this was quite easy because of the existing group. In other municipalities, it was very hard to find people with willingness in engaging for community development (DAmyanovic \& ReINWALD 2011b). This is the first central challenge in implementing a top-down strategy with a participatory (bottom-up) setting. Social capital - a network of people with different competences is necessary to build up such a group.

During the first phase, different information sessions were organised. The core team got informed about the possibilities of village renewal, and methodological and didactic concepts were coordinated related to the needs of the community, as well as with the village-renewal department of the office in the Burgenland state government. During a village festival, the village-renewal core group presented themselves and their activities to the inhabitants. At the same time, an activating survey on the use of open space in the village started.

During the second phase, the village-renewal concept - a document with the selected strategies and measures - was developed in an intensive participation process. The participation process (Fig. 4) itself consisted of different discussion and exchange forms, like general public meetings, core-group meetings or special forms of participation for certain groups. Invitations to the village discussions were sent to each household in the community. The first village discussion started with the presentation of results from the analysis accomplished by the process facilitators and the core group, and the presentation of the fields of action for the village-renewal concept, which was extended and adopted by the inhabitants in the respective meeting. The locals were also encouraged to submit own (project) proposals.

But only 60 people took part in this meeting - quite a lot for a small municipality, but by far no comprehensive participation. Groups like young people or women were underrepresented and nearly no foreigners (about 18\% of the population in Parndorf/ Pandrof) took part. It was tried to broaden the possibilities to take part in the villagerenewal process so that at least the interests and project ideas of these groups could be included. The village-renewal core group took part at the village fair, walks through the municipality were offered to discuss projects in situ or local meetings for the neighbours of a planned park were organised. So, at least the basis for participation was broadened, but compared to all inhabitants, only a small group took part and worked for their municipal development. This is the second central challenge in village-renewal processes regarding social capital. It is not possible to really incorporate all interests and groups in a process. Care obligation, full employment, but also reluctance - just to mention some reasons - hinder people to take part in such processes. So, the social capital could not fully be used for municipal development. 
The next step was to collect all project proposals and ideas in order to prioritise them. After this step, a detailed strategic document including aims and strategies, fields of action and concrete measures was elaborated with the village-renewal core group. This concept was presented to the public and discussed within a public meeting and, after some adjustments, unanimously adopted also in the municipal council. This is the formal basis to apply for funding from the Burgenland state government to implement measures and projects, which were defined in the concept. This is a central link between the village-renewal group and the official political decision makers in the municipality. With the decision on the concept, politicians commit themselves to implement the strategy.

Figure 4: Some impressions from the various participation events

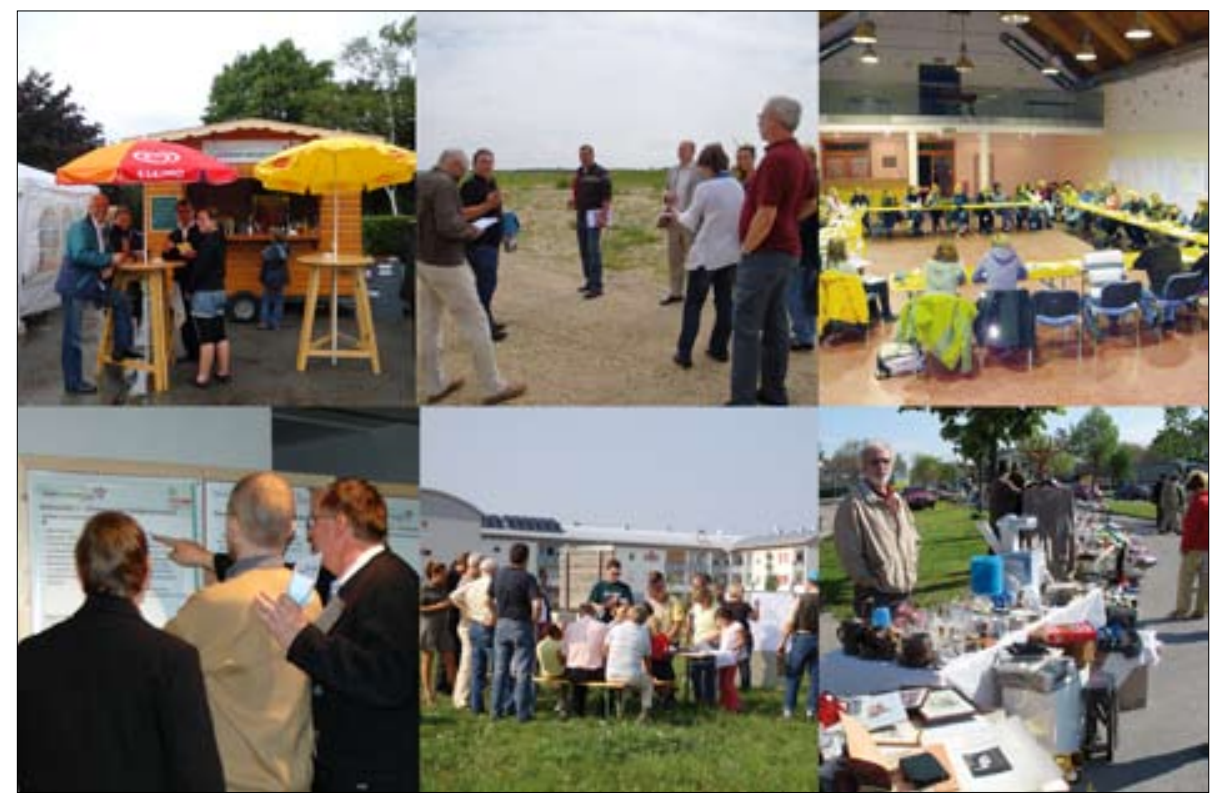

The third phase - project development and implementation - already started parallel to the second phase, in order to make the village-renewal process visible in the municipality. Two of the collected 49 village-renewal projects were selected as starting projects: the improvement of playgrounds and the design of a neighbourhood square. This phase is also crucial in village-renewal processes. On the one hand, it is easier to find people for a concrete project. For example: From a new park in front of their house, they profit directly. But if they are not directly influenced by a project, their interest decreases. Only for the 'common good', it is hard to find people who are engaged. But, on the other hand, these development and implementation processes of projects need time, endurance, and different forms of social capital. You have to develop the project, 
make plans, coordinate them with the municipality so that a budget is foreseen (one year in advance), make the application at the village-renewal office, wait until it is approved, build it and finally make the billing of costs. This process is complicated and lasts long. This is the third central challenge in village-renewal processes regarding social capital. You need people with different social capital - organisers, planners, strategists, executors, and so on.

The village-renewal group implemented funded projects like the restoration of four children playgrounds, the building of a new one, the installation of drinking water fountains on playgrounds, measures for traffic calming in a street or the retrofitting of street lamps. The group is still active. Beside the funded investment project, a lot of social projects like a community library or social events and festivals were organised. These projects especially need social capital, because no real capital has to be invested - the projects just have to be organised. By connecting and bringing people together, social capital is generated. which is necessary for a sustainable village renewal.

In order to implement the "comprehensive village renewal" with the LA 21 approach, new structures in the federal state administration of Burgenland have been established. Several projects launched to distribute information about the village-renewal programme were implemented. But the most important fact was the installation of professional process facilitators. These, who are in charge of the process monitoring, are people from the region who got a training, including the necessary contents of the village-renewal process and information about project management (NetzweK der burgenländischen "LA 21" - ProzessbegleiterInnen 2009). These persons play an important role in the process. Their task is to lead and structure the process, establish continuity, and build up a core team to start and supervise the whole process at community level. Having this position, they are an important link between the federal state administration, the funding agencies, the local politics, and the residents of the village. Their crucial position became also visible in the evaluation of the programme (DAMYANOVIC \& REINWALD 2011b). In many municipalities, the villagerenewal process fell asleep as the process facilitators left the municipality. This is the fourth central challenge in village-renewal processes in relation to social capital. During the accompanied processes, enough social capital has to be built up to ensure a long-lasting, active engaged group of people, interested in municipality development.

\section{Discussion and conclusions}

Participative development measures are applied with the hope that the development projects would be more successful and sustainable if the local people are engaged in this process. For Viscri/Deutsch-Weißkirch, we identified the following features of the development process: It is mainly an ongoing learning by doing procedure, with a step by step development of measures and projects according to the needs of the 
community. The strategy of Viscri/Deutsch-Weißkirch has a limited transferability to other communities due to several reasons: It mainly relies on the existence of authentic valuable cultural heritage; it is strongly dependant on local mobilising agents and leader personalities, although striving for self-sufficiency; the development is still dependant on initial project financing, and, finally, it faces meagre political or administrative support. Worth to mention is also the fact that it is a long-term endeavour, with effort in activating the population. Yet, with visible and valuable economic and social result: an empowered community; stronger self-esteem than before this type of development started; the locals appropriated also a consciousness about their improved quality of life and well-being in comparison with the neighbouring communities and consider it also the success of their own commitment. It cannot be denied that the locals take part and engage in the projects and measures partly out of personal interests, but, at the same time, they contribute to the general well-being of the community.

Initiatives of participative bottom-up development strategies struggle with numerous impediments in Romania. On the one hand, there are administrative constraints like the deficit of legal background, regulations, and structures for the implementation of such endeavours, the lack of political will and the incipient stage for decentralisation of power and of decision-making processes. On the other hand, major socio-cultural obstacles hinder this kind of civil involvement: lack of experience and tradition of participation, caused considerably by the several decades of a political system, which allowed no private initiatives. Further on, significant is also the absence of trust in the municipalities and administration, as well as no interest from the affected population.

For Parndorf/Pandrof and Burgenland, the following features of the villagerenewal processes could be identified as success factors: a comprehensive overall strategy, a clear structure of procedure and a support programme whose minimal standards help the municipalities to implement participation processes in the sense of the LA 21. In the manuals for the village-renewal processes, mainly the how and not the what was defined. So, every municipality could tailor their process according to their needs. The political and administrative institutions support the strategy as acknowledged instruments of rural development, being actually in accordance with the national and federal states agenda.

The high financial support for process facilitators (between 60 and $80 \%$ of the costs) makes it possible for nearly every municipality to start a participation process. Also for investment-related projects, funding was provided covering plenty of measures regarding municipal development (e.g. local supply, playgrounds, community halls, mobility, etc.). Nearly 290 village-renewal projects were implemented by 131 municipalities.

But one of the central aims of the processes was to support social cohesion by initiating community-fostered projects. In the mid-term evaluation, it became visible, that nearly all projects reported by the municipalities were investment-related projects - no social projects were visible (DAmYNovic \& ReInwald 2014). Upon request, the 
village-renewal groups told us that they did not need money for these projects because they organised the process on their own, with no or low costs (like neighbourly help) or they could not manage to implement projects because the effort to make an application for these small-scale projects was too big. One could learn from this that social capital is central especially for projects within the social sector. Municipalities who had a village-renewal group, with a lot of social capital, managed to be more successful and showed a longer-lasting success.

Regarding the central challenges identified in the village-renewal processes in Parndorf/Pandrof and the other village-renewal processes in the Federal State of Burgenland - build up a core group, incorporate different groups, bring different people together and maintain a sustainable village-renewal group - the central challenge is to use the available social capital in the municipalities. Different forms of social capital are necessary to implement successful village-renewal processes.

Especially the meso-level of social capital is important in village-renewal processes. The central challenge is to find a suitable group with different social capital on micro-level and support the building up of relationships between those. Additionally, an amount of binding social capital in the group is necessary to keep the group alive, and bridging social capital is necessary to mediate between the interests of the different groups in the municipality (who may not all be represented in the villagerenewal core groups), the aims of the political representatives of the municipalities and the possibilities of the funding agency. The process facilitators play a central role in mobilising, establishing and increasing social capital, as well as in building organisational structures to support the building of social capital (WIESINGER 2007).

Besides many tangible outcomes of participatory development, TuFTE and MefaLOPULOS (2009) underline the following major possible outcomes, experienced also in our cases:

- psychological and social outcomes, such as increased feelings of ownership of a problem and a commitment to doing something about it (pride, self-esteem, identity, common welfare);

- improvement of competences and capacities required to engage with the defined development problem (skills, professional knowledge, cooperation, team work, etc.);

- actual influence on institutions that can affect an individual or community (like the experience of Viscri/Deutsch-Weißkirch influencing the policy of cultural heritage protection and the perspectives of biological sewage systems).

Comparing the experiences gained in Viscri/Deutsch-Weißkirch and Parndorf/ Pandrof, the central challenges are - despite totally different circumstances and framework conditions - quite similar and are mostly depending on the aspect of social capital. 


\section{References}

Ahmad M.S., Talib N.Bt.A. (2011), Decentralization and participatory rural development: a literature review. In: Contemporary Economics, 5, 4, 58-67.

Alexiu T.M., Lazăr T.A., Baciu E.L. (2011), Community participation and involvement in social actions. In: Transylvanian Review of Administrative Sciences, 33E, pp. 5-22.

Amt der Burgenländischen LANDesRegierung (ed.) (2012), Landesentwicklungsprogramm Burgenland. Mit der Natur zu neuen Erfolgen. Eisenstadt.

Amt der Vorarlberger Landesregierung, Büro für Zukunftsfragen (ed.) (2010), Freiwilliges Engagement und Sozialkapital. Bregenz. - <www.vorarlberg.at/vorarlberg/ umwelt_zukunft/zukunft/buerofuerzukunftsfragen/weitereinformationen/sozialkapital/ sozialkapitalstudien/freiwilligesengagementund.htm> (Accessed on 18 July 2016)

ARnSteIn S.R. (1969), A ladder of citizen participation. In: Journal of American Planning Association, 35, 4, pp. 216-224.

ARTNER F. (2004), "Burgenland macht sich auf den Weg". In: Bundesministerium für Landund Forstwirtschaft, Umwelt und Wasserwirtschaft. Lokale Agenda 21 in Österreich. Beteiligung bewegt. Wien, Eigenverlag.

Austrian Federal Chancellery, Federal Ministry of Agriculture, Forestry, Environment and Water Management (BMLFUW) (eds.) (2008 German, 2011 English), Standards of public participation. Recommendations for good practice Vienna. $<$ https://de.scribd.com/ doc/69122661/Oebs-Standards-Engl-Finale-Web> (Accessed on 14 May 2016)

Austrian Federal Ministry for Education, Arts and Culture (BMUKK), Austrian Federal Ministry of Agriculture, Forestry, Environment and Water Management (BMLFUW) (eds.), (2010), Sozialkapital, Das Leben im Netz sozialer Beziehungen, Bregenz. $<$ http./www.lebensministerium.at/umwelt/nachhaltigkeit/green_economy/sozialkapital/ Sozialkapital.html> (Accessed on 19 July 2016)

BALOGH M. (2012), Non-governmental organizations - factors for local development. In: Transylvanian Review of Administrative Sciences, Special Issue, pp. 19-31.

BinNS T., Hill T., Nel E. (1997), Learning from the people - participatory rural appraisal, geography and rural development in the 'new' South Africa. In: Applied Geography, 17, 1, pp. 1-9.

Bowles S., GinTis H. (2002), Social capital and community governance. In: The Economic Journal, 112, 483, pp. 419-436.

BundESPRESSEDIENST (ed.) (2000), Das politische System in Österreich, Vienna. <www.politische bildung.at/upload/polsystem.pdf> (Accessed on 19 July 2016)

BundSCHUH-RIESENEDER F. (2008), Good governance: characteristics, methods and the Austrian examples. In: Transylvanian Review of Administrative Sciences, 24E, pp. 26-52.

BURGENLÄNDISCHER LANDESENTWICKLUNGSPLAN, Verordnung der Burgenländischen Landesregierung vom 19. Juli 1994, mit der ein Landesentwicklungsprogramm erlassen wird (LEP 2011) StF: LGBl. Nr. 71/2011.

CAstle E.N. (2002), Social Capital: an Interdisciplinary Concept. In: Rural Sociology, 67, 3, pp. 331-349.

ChAmbers R. (1994a), The origins and practice of participatory rural appraisal. In: World Development, 22, 7, pp. 953-969. 
Chambers R. (1994b), Participatory rural appraisal (PRA) analysis of experience. In: World Development, 22, 9, pp. 1253-1268.

Chaskin R.J. (2001), Building community capacity. In: Urban Affairs Review, 36, 3, pp. 291323.

Damyanovic D., Reinwald F. (2009), Dorferneuerung in Mörbisch am See. Frauen und Männer, Jung und Alt engagieren sich gemeinsam für die Dorfentwicklung. Wien, Universität für Bodenkultur.

Damyanovic D., Reinwald F. (2010), Leitbildbericht Dorferneuerung Parndorf. Dorferneuerung ist mehr! Wien, Universität für Bodenkultur.

Damyanovic D., Reinwald F. (2011a), Umfassende Dorferneuerung im Burgenland als Planungsinstrument zur nachhaltigen Entwicklung des ländlichen Raumes - eine Chance? In: zoll+ Österreichische Schriftenreihe für Landschaft und Freiraum, 18, pp 18-25.

Damyanovic D., Reinwald F. (2011b), Abschlussbericht Wirksamkeitsprüfung der umfassenden Dorferneuerung im Burgenland. Verein UNSER DORF. Wien, Universität für Bodenkultur.

Damyanovic D., Reinwald F. (2014), The "Comprehensive Village Renewal Programme in Burgenland" as a means of strengthening the social capital in rural areas. In: European Countryside, 1, pp. 18-35.

Dangschat J., Breitfuss A. (2000), Lokale Agenda 21 in Wien. Von der Betroffenenbeteiligung zur Akteurskooperation. Vienna, TU Vienna - Institute for Urban and Social Research.

De Campos Guimarẽes J.P. (2009), Participatory approaches to rural development and rural poverty alleviation. The United Nations Economic and Social Commission for Asia and the Pacific (ESCAP). <http://sergiorosendo.pbworks.com/f/Guimaraes+2010+participatory_ rural.pdf $>$ (Accessed on 12 May 2016)

DefiLIPPIS J. (2001), The myth of social capital in community development. In: Housing Policy Debate, 12, 4, pp. 781-806.

DiNCĂ D. (2012), Rural administration in Romania: evaluation of current state. In: Transylvanian Review of Administrative Sciences, 36E, pp. 77-91.

Deustch-Weisskirch (ed.), http://www.deutsch-weisskirch.ro/?page_id=7 (Accessed on 10 July 2016).

ElBe J. (2011), Die Wirksamkeit von Sozialkapital in der Regionalentwicklung. Erprobung eines anwendungsorientierten Analysekonzepts am Beispiel des Modellvorhabens „BioenergieRegionen". Aachen, Shaker Verlag.

European Union, Directorate-General for Agriculture and Rural Development (ed.) (2010), Rural development in the European Union. Statistical and economic information report 2010. <http://ec.europa.eu/agriculture/agrista/rurdev2010/RD_Report_2010.pdf > (Accessed on 10 July 2016)

FALK I., KILPATRICK S. (2000), What is social capital? A study of interaction in a rural community. In: Sociologia Ruralis, 40, 1, pp. 87-110.

Federal Ministry of Agriculture, Forestry, Environment and Water Management (BMLFUW) (ed.), Austrian Rural Development Programme 2014-2020 (Version 2.1). <https://www. bmlfuw.gv.at/land/laendl_entwicklung/leprogramm.html> (Accessed on 12 May 2016)

Federal Ministry of Agriculture, Forestry, Environment and Water Management (BMLFUW) (ed.), (2002), The Austrian strategy for sustainable development. An initiative of the Federal Government, Vienna. <www.nachhaltigkeit.at/assets/customer/Downloads/ Strategie/strategie020709_de.pdf $>$ (Accessed on 11 July 2016). 
Federal Ministry of Agriculture, Forestry, Environment and Water Management (BMLFUW), Austrian Society for Environment And Technology (ÖGUT) (eds.) (2007), The public participation manual. Shaping the future together. Vienna.

Food and Agricultural Organisation (FAO) - RDD (ed.) (2005), An approach to rural development: participated and negotiated territorial development. Rome, FAO. $<$ http:// www.fao.org/3/a-ak228e.pdf $>$ (Accessed on 22 July 2013).

Funuyama F. (2010), Social capital, civil society and development. In: Third World Quarterly, 22,1, pp. 7-20.

FunDATIA ADEPT (ed.), http://www.fundatia-adept.org/ (Accessed on 10 July 2016)

Gehmacher E. (2009), Sozialkapital - Chancen und Grenzen der Methodik. In: SWS Rundschau - Die Zeitschrift der Sozialwissenschaftlichen Studiengesellschaft, 1, pp. 103-109.

Gemeinde Parndorf (ed.) (2013), Unsere Gemeinde. Parndorf. Daten und Fakten. http://www. gemeinde-parndorf.at/de/gemeindeportrait/unsere_gemeinde (Accessed on 25 June 2013)

Groottaert C., van Bastelaer T. (2002), Understanding and measuring social capital. A multidisciplinary tool for practitioners. Washington D.C.,The World Bank. $<\mathrm{http}$ ://documents.worldbank.org/curated/en/221161468741319675/Understandingand-measuring-social-capital-a-multidisciplinary-tool-for-practitioners $>$ (Accessed on 18.7.2016)

HANKE M. (2011), Sozialkapital in partizipativer Stadtentwicklung am Beispiel der Lokalen Agenda 21 Wien. Diploma Thesis, University of Vienna. Vienna.

Haruța C., Radu B. (2010), Citizen participation in the decision-making process at local and county levels in the Romanian public institutions. In: Transylvanian Review of Administrative Sciences, 31E, pp. 76-92.

HusÁk J. (2012), Synergy of social and human capital in rural development - Czech and German cases. In: European Countryside, 4, pp. 240-250.

ILOVAN O.-R. (2006), Năsăudului Land in ,,after 1989” Romania - between effervescence and decline. In: Michalski T. (ed.), The Geographical Aspects of the Transformation Process in Central and East-Central Europe, pp. 161-170. Peplin, Wydawnictwo Bernardinum.

Ilovan O.-R., Maroşı Z. (2015), Leadership and regeneration of the Transylvanian villages in the region of Rupea. In: Banini T., Police F. (eds.), Semestrale di Studi e Ricerche di Geografia. Rural development policy and local identities in the European Union, XXVII, 1, pp. 63-70.

Ilovan O.-R., Sochircă E. (2011), Geodemographic problems in the Republic of Moldova and in Romania, after 1990. In: Studia UBB Geographia, LVI, 1, pp. 105-116.

Jordan P., Havadi-Nagy K.X., Maroși Z. (2016), Tourism as a driving force in rural development: Comparative case study of Romanian and Austrian villages. In: Tourism - An International Interdisciplinary Journal, 64, 2, pp. 203-218.

Liaison Office of the Federal Provinces (2003), Declaration on the further development of the environmental policy in Austria; Joint Declaration on Local Agenda 21 in Austria. <www. nachhaltigkeit.at/assets/customer/Downloads/documents/gemeinsame_20eerkl_rung_ lurk_resolution_engl_10_03.pdf> (Accessed on 11 July 2016).

Minai Eminescu Trust (ed.), http://www.mihaieminescutrust.org/content/nd_village.asp? $\mathrm{n}=91$ (Accessed on 10 July 2016)

NetzWerk der BURGenLÄndischen "LA 21" - ProzessbegleiterInNen (ed.) (2009), Dorferneuerung. Neu. Die burgenländischen "La 21" - ProzessbegleiterInnen. Damit die 
Zukunft Profil bekommt. Angried - Zurndorf, Netzwerk der burgenländischen "LA 21" - ProzessbegleiterInnen.

Nistor L., Tîrhaș C., Iluț P. (2011), Linkages between informal and formal social capital and their relations with forms of trust. A focus on Romania. In: Transylvanian Review of Administrative Sciences, 34E, pp. 155-174.

OAKLEY P. et al. (1991), Projects with people: The practice of participation in rural development. Geneva, International Labour Office.

Österreichische BundesRegierung (ed.) (1996 [1994]), Nationaler Umweltplan (NUP), 3. Auflage, Wien.

Österreichische Gesellschaft Für Umwelt und Technik (ÖGUT), Ministry of the Environment (eds.) (2002), The Strategic Group on Participation. <http://www.partizipation.at/strate gic_group.html> (Accessed on 14 May 2016)

Pearce J. (1993), NGOs and social change: agents or facilitators? In: Development in Practice, 3, 3, pp. 222-227.

PNDR 2014-2020, Official version 1 - 1 July 2014. <http://www.madr.ro/docs/dezvoltarerurala/programare-2014-2020/PNDR_2014_-_2020_01.07.2014.pdf $>$ (Accessed on 12 May 2016)

Putnam R.D. (1993), Making Democracy Work: Civic Traditions in Modern Italy. Princeton, Princeton University Press.

SPESP (ed.) (2000), Study Programme on European Spatial Planning. <http://www.mcrit.com/ SPESP/SPESP\%20Report\%20-\%20final\%20version.htm> (Accessed on 11 July 2016)

Tufte T., Mefalopulos P. (2009), Participatory communication a practical guide. Washington, DC, The International Bank for Reconstruction and Development/The World Bank. $<$ http://siteresources.worldbank.org/EXTDEVCOMMENG/Resources/Participatory communication.pdf $>$ (Accessed on 12 May 2016)

United Nations (ed.) (1992), AGENDA 21, United Nations Conference on Environment \& Development Rio de Janerio, Brazil, 3 to 14 June 1992. <www.sustainabledevelopment. un.org/content/documents/Agenda21.pdf> (Accessed on 11 July 2016).

van Heck B. (2003), Participatory development: guidelines on beneficiary participation in agricultural and rural development, $2^{\text {nd }}$ edition, Rome, The Rural Institutions and Participation Service, Rural Development Division Food and Agriculture Organization of the United Nations. <ftp://ftp.fao.org/docrep/fao/007/ad817e/ad817e00.pdf $>$ (Accessed on 22 July 2013)

VISCRISOCKEN (ed.), http://viscrisocken.insopro.org/ (Accessed on 10 July 2016)

Wiesinger G. (2007), Social capital and rural development. In: OedL-Wieser T. (ed.) (2007), Zeitreisende im ländlichen Raum. Diskurse - Re.Visionen (= Research Report of the Federal Institute for Less Favoured and Mountainous Areas, 57), pp. 97-112. Wien, Federal Institute for Less Favoured and Mountainous Areas. 




\section{ISR-Forschungsberichte}

1 Zoltán CsÉFalvay und Walter RoHn (1991): Der Weg des ungarischen Arbeitsmarktes in die duale Ökonomie

2 Elisabeth Lichtenberger (Hg., 1991): Die Zukunft von Ostmitteleuropa. Vom Plan zum Markt

3 Marlies Schulz (1991): Der Tauschwohnungsmarkt in der zentralistischen Planwirtschaft - das Beispiel von Ostberlin

4 Helga Sснмірт (1991): Die metropolitane Region Leipzig - Erbe der sozialistischen Planwirtschaft und Zukunftschancen

5 Hugo Penz (1992): Entwicklungsstruktur und Zukunft von ländlicher Siedlung und Landwirtschaft in der ČSFR und in Ungarn

6 Zoltán Cséfalvay und Walter RoHn (1992): Die Transition des ungarischen und Budapester Wohnungsmarktes

7 Alina MuzioŁ-Węctawowicz (unter Mitarbeit v. Josef Kohlbacher, 1992):

Die Transformation des Wohnungswesens in Polen - eine Analyse des Warschauer Wohnungsmarktes

8 Grzegorz WęcŁawowicz (unter Mitarbeit v. Josef Kohlbacher, 1993): Die sozialräumliche Struktur Warschaus - Ausgangslage und postkommunistische Umgestaltung

9 Markus SEIDL (1993): Stadtverfall in Bratislava

10 Heinz Fassmann, Josef Kohlbacher und Ursula Reeger (1993): „Suche Arbeit“ - Eine empirische Analyse über Stellensuchende aus dem Ausland

11 Heinz Fassmann, Zoltán Cséfalvay und Walter Rohn (1993): Regionalstruktur im Wandel - Das Beispiel Ungarn

12 Ursula BAUer (1994): Europa der Regionen - Zwischen Anspruch und Wirklichkeit

13 Heinz Fassmann, Josef Kohlbacher und Ursula Reeger (1995): Die „neue Zuwanderung" aus Ostmitteleuropa - Eine empirische Analyse am Beispiel der Polen in Österreich

14 Heinz Fassmann (Hg., 1995): Immobilien-, Wohnungs- und Kapitalmärkte in Ostmitteleuropa. Beiträge zur regionalen Transformationsforschung

15 Heinz Fassmann und Christiane Hintermann (1997): Migrationspotential Ostmitteleuropa. Struktur und Motivation potentieller Migranten aus Polen, der Slowakei, Tschechien und Ungarn

16 Heike JÖNS und Britta KLAGGE (1997): Bankwesen und Regionalstruktur in Ungarn

17 Konrad Scherf (1998): Die metropolitane Region Berlin. Genese und Niedergang, Revitalisierung und Innovation 
18 Heinz Fassmann, Christiane Hintermann, Josef Kohlbacher und Ursula REEGER (1999): „Arbeitsmarkt Mitteleuropa“. Die Rückkehr historischer Migrationsmuster

19 Zoltán CséFalvay (1999): Die Wettbewerbsfähigkeit der österreichischen Großstädte. Theoretische Ansätze und empirische Befunde

20 Axel Borsdorf und Michaela PaAl (Hg., 2000): Die ,alpine Stadt“ zwischen lokaler Verankerung und globaler Vernetzung. Beiträge zur regionalen Stadtforschung im Alpenraum

21 Walter Rohn (2000): Forschungseinrichtungen in der Agglomeration Wien. Stellung im Innovationsprozeß und Einbindung in innovative Netzwerke

22 Vera MAYER (2000): Regionale Innovationspotentiale und innovative Netzwerke der Industrieunternehmen in der metropolitanen Region Wien. Ergebnisse einer Unternehmensbefragung

23 Axel Borsdorf (Hg., 2000): Perspectives of Geographical Research on Latin America for the 21st Century

24 Wolfgang Berger (2001): Photovoltaics in Europe in the Year 2020. Utilities, Sustainable Development and Culture

25 Heinz Fassmann, Josef Kohlbacher und Ursula ReEger (in Zusammenarbeit mit Katharina DEMEL und Irene STACHER, 2001): Integration durch berufliche Mobilität? Eine empirische Analyse der beruflichen Mobilität ausländischer Arbeitskräfte in Wien

26 Walter ROHN (2002): Regelung versus Nichtregelung internationaler Kommunikationsbeziehungen. Das Beispiel der UNESCO-Kommunikationspolitik

27 Vera MAYER (2002): Wohnpräferenzen von Jugendlichen in Wien. Ein Beitrag zur Kultur und Sozialgeographie des Wohnens

28 Michael JanoschKa (2002): Wohlstand hinter Mauern. Private Urbanisierungen in Buenos Aires

29 Axel Borsdorf und Christof ParnReiter (Hg., 2003): International Research on Metropolises - Milestones and Frontiers

30 Heinz Fassmann, Josef Kohlbacher und Ursula Reeger (2004): Polen in Wien. Entwicklung, Strukturmerkmale und Interaktionsmuster

31 Josef Kohlbacher und Ursula Reeger (2005): Aus aller Herren Länder? Wien als Studienort und internationale Bildungsmetropole

32 Josef Kohlbacher und Ursula Reeger (2006): „Gespanntes Nachbarschaftsverhältnis?" Eine empirische Analyse des interethnischen Zusammenlebens in unterschiedlichen Wohnbaukategorien in Wien

33 Josef Kohlbacher und Ursula Reeger (2006): Die Dynamik ethnischer Wohnviertel in Wien. Eine sozialräumliche Longitudinalanalyse 1981 und 2005 
34 Wolfgang Bosswick, Heinz Fassmann, Josef Kohlbacher and Doris LÜKEN-KLASSEN (2007): Housing and Residential Segregation of Migrants. A state-of-the-art report

35 Josef Kohlbacher und Ursula Reeger (2008): Staatsbürgerschaftsbonus beim Wohnen? Eine emprische Analyse der Unterschiede zwischen eingebürgerten und nichteingebürgerten Zuwanderern/-innen hinsichtlich ihrer Wohnsituation in Wien

36 Heinz Fassmann and Yvonne Franz (Hg., 2010): Integration Policies on the Local Level: Housing Policies for Migrants. Examples from New York City, St. Paul, Antwerp, Vienna and Stuttgart

37 Josef Kohlbacher, Ursula Reeger and Philipp Schnell (2012): Neighbourhood Embeddedness and Social Coexistence. Immigrants and Natives in Three Urban Settings in Vienna

38 Peter Jordan (Hg., 2012): Regional Development and Regionalisation in the Adriatic Space. Proceedings of the 3rd Conference of the Adriatic Forum, Vienna, September 23-25 2010

39 Josef Kohlbacher und Ursula Reeger (2013): Von der Nische ins Zentrum? Unternehmer mit türkischem oder exjugoslawischem Migrationshintergrund in der Wiener Wirtschaft

40 Robert Musil und Jakob Eder (2013): Wien und seine Hochschulen. Regionale Wertschöpfungsefekte der Wiener Hochschulen

41 Robert Musil und Jakob Eder (2015): Local Buzz in der Wiener Forschung. Wissensintensive Cluster zwischen lokaler Einbettung und internationaler Orientierung

42 Peter Jordan (Hg., 2017): 10 Years of EU Eastern Enlargement - The Geographical Balance of a Courageous Step. Proceedings of the Symposion in Vienna, 3-4 December 2014 
